\title{
CSR REPORTING AS A PRODUCT OF SOCIAL ACCOUNTING
}

\author{
Grażyna Michalczuk ${ }^{8}$ \\ Urszula Konarzewska9
}

Received: February 28, 2018 / Revised: May 10, 2018 / Accepted: June 28, 2018

(C) Association of Economists and Managers of the Balkans, 2018

\begin{abstract}
The development of the concept of corporate social responsibility has become the new and extremely important challenge for accounting. It is necessary that its methods and solutions allow for reflect newer and newer information needs. Because of its systemic character, accounting has to evolve to be able to constitute a basic information system. The development of social accounting is a welcome direction in this regard. It aims to identify measure and present the social and environmental issues related to the functioning of company. The CSR report is a tool for providing information related to corporate social responsibility. It shows the influence of company's activity on various group of stakeholders, by ensuring detailed data about management regarding aspects such as ethics, ecology, diversity in the workplace and community involvement. Instead of preparing corporate social responsibility reports some companies publish integrated reports which present in one document both financial and social issues in a holistic manner. The aim of the article is to present the problem of CSR reporting within the context of social accounting. The main subject of researches is the evaluation of trends associated with the publishing social reports in the national and international context as well as an analysis of the content of reports dealing with corporate social responsibility prepared by selected companies operating in Poland. The article is based on the analysis of Polish and English literature, selected studies and databases connected with the practice of CSR reporting as well as the reports prepared by companies covered by the survey. Results of the research lead to the conclusion that social reporting is a rapidly growing field in both national and international context. This is reflected by the number of reports dealing with corporate social responsibility submitted by companies to a databases connected with the practice of Corporate Social Responsibility reporting. However, the analysis of the content of this type of reports showed that comparison of data contained within documents prepared by individual companies may pose a problem.
\end{abstract}

Keywords: social accounting, CSR reporting, integrated reporting

\section{JEL Classifications D22 $\cdot$ M14 $\cdot$ M41}

This paper was presented at the Second International Scientific Conference on Economics and Management - EMAN 2018, March 22 2018, Ljubljana, Slovenia, www.eman-conference.org

\footnotetext{
¿rażyna Michalczuk g.michalczuk@uwb.edu.pl
}

\footnotetext{
${ }^{8}$ Faculty of Economics and Management, University of Bialystok, ul. Warszawska 63, 15-062 Białystok, Poland;

${ }^{9}$ Faculty of Economics and Management, University of Bialystok, ul. Warszawska 63, 15-062 Białystok, Poland
} 


\section{INTRODUCTION}

In the context of the dynamic changes in enterprises and their environment, the rationality of decisions and the undertaking of an informed market game are conditional on access to information. For that reason, stakeholders report the need of increased informational openness of enterprises. They expect useful information for making decisions, both current and predictive, which are presented in transparent, comprehensible form and allow creating view on the enterprise value as well as financial and non-financial factors which shape this value (Michalczuk, 2013).

However, practice shows that financial reporting, which is a basic communication tools, is not in a position to meet the growing information needs of various stakeholders, particularly in the context of corporate social responsibility and sustainable development. Therefore, efforts are being undertaken to develop a system which will allow mutual understanding and reduce asymmetry between enterprise and its stakeholders (Marcinkowska, 2013).

The aim of the article is to present the problem of CSR reporting within the context of social accounting. The main subject of researches is the evaluation of trends associated with the publishing social reports in the national and international context as well as an analysis of the content of reports dealing with corporate social responsibility prepared by selected companies operating in Poland.

\section{SOCIAL ACCOUNTING AS A BROADER DIMENSION OF ACCOUNTING}

Despite various form of transmission, accounting is the basic system, in which the economic information plays a crucial role. This follows from prevalence of this system. It has been created to communication to the stakeholders the real situation of company operating in the market. It also describe a company's ability to generate economic benefits and its efficiency of the use of resources. Accounting, being a universal, flexible and subjective information system enables the creation of a numerical "image" of generation, distribution and flow of the value and settlements between economic operators related thereto (Michalczuk, 2013). In social terms, accounting registers economic events regardless of real basis. This phenomenon has been aptly articulated by W. Handel (1982), who stated that ,things may exist independently of our accounts, but they have no human existence until they become accountable. Things may not exist, but they may take on human significance by becoming accountable".

In the traditional sense, accounting generates information, mainly of a financial nature. However, nowadays it is shaped by the environment in which its system is functioning (Zuchewicz, 2015). Recently, this environment is exerting increasing pressure on provide information showing not only financial performances but also non-financial data on intangible generators of company's value, corporate social responsibility as well as sustainable development (Bonsón, Bednárová, 2015; Michalczuk, 2013).

In this context broader dimension of accounting that is social accounting is discussed more and more nowadays. Undoubtedly, this is a wide term that includes a different forms and tools. Social accounting can be analyzed as a statistical-economic discipline used to capture economic processes on a macroeconomic scale (Biadacz, 2017). In terms of microeconomic, social accounting can be defined as ,the process of communicating the social and environmental effects of organizations' economic actions to particular interest groups within society and to society at large (Gray, Owen, Maunders, 1987). 
Therefore, it is reasonable to assume that social accounting includes a set of organizational activities that deals with the measurement, analysis and reporting of the social performance to concerned groups, both within and outside the organization (Islam, 2015). This approach to accounting extends its scope and means extending beyond the area of traditional financial settlement (Gray, Owen, Maunders, 1987).

\section{CORPORATE SOCIAL RESPONSIBILITY REPORTING}

The development of social accounting is reflected in evolution of reporting system. This is because results of the measurements carried out within the social accounting must be reflected in reports prepared by the companies. The CSR report is a basis tool for providing information related to corporate social responsibility. It shows the influence of company's activity on various group of stakeholders, by ensuring detailed data about management regarding aspects such as ethics, ecology, diversity in the workplace and community involvement. More and more companies go beyond the scope of CSR reports and publish integrated reports, which open the opportunities for include in one document the information being generated these days by financial statement, management commentary, sustainability report and the other non- financial reports e.g. intellectual capital report (Michalczuk, Konarzewska, Mikulska, 2017).

Regardless of the form used by individual companies, corporate social responsibility reporting is becoming a common practice. This is reflected in research described in the report „The road ahead. The KPMG Survey of Corporate Social Responsibility Reporting 2017'. The research was conducted on 4.900 companies in 49 countries and regions and concerned with global trends in CSR reporting. The final results show that $72 \%$ of analyzed companies publish reports concerning corporate social responsibility. The situation for global business leaders is even more preferably. The results indicated that $93 \%$ of 250 largest companies by revenue based on the Fortune 500 ranking of 2016 prepare this kind of reports (KPMG Survey of Corporate Social Responsibility Reporting 2017).

When analysing the corporate social responsibility reporting by geographical segments it turns out that North and Latin America is the leading region in this respect. The overall CSR reporting rates in this region has reached 83\% in 2017. Subsequently the Asia and Pacific (77\%) and Europe (73\%) were classified. The lowest reporting rate was recorded in the Middle East and Africa in which $52 \%$ of companies publish reports related to corporate social responsibility (KPMG Survey of Corporate Social Responsibility Reporting 2017). In the light of presented results, can be expected the growth in CSR reporting in Europe. This is due to the implemented the Directive 2014/95/EU of the European Parliament and of the Council which requires on large public interest entities to disclosure of non-financial and diversity information concerning environmental matters, social and employee-related matters, respect for human rights, anti-corruption and bribery matters (Directive 2014/95/EU).

The data contained within the KPMG's survey also allow to indicate countries which are the world's leaders in the field of corporate social responsibility reporting (figure 1). These include: Great Britain, Japan, India, Malaysia, France, Denmark, South Africa, United States and Mexico. Against this background, the practice of polish companies significantly deviates not only from the world's best practices but also from the global and European average. This is due to the fact that only $59 \%$ of the largest polish companies decide to prepare a reports containing information on corporate social responsibility. However, it should be emphasized that this result increased by five percentage points between 2015 and 2017. 
Figure 1: National rates of Corporate Social Responsibility Reporting in 2017.

CSR reporting rates by country $(\%)$
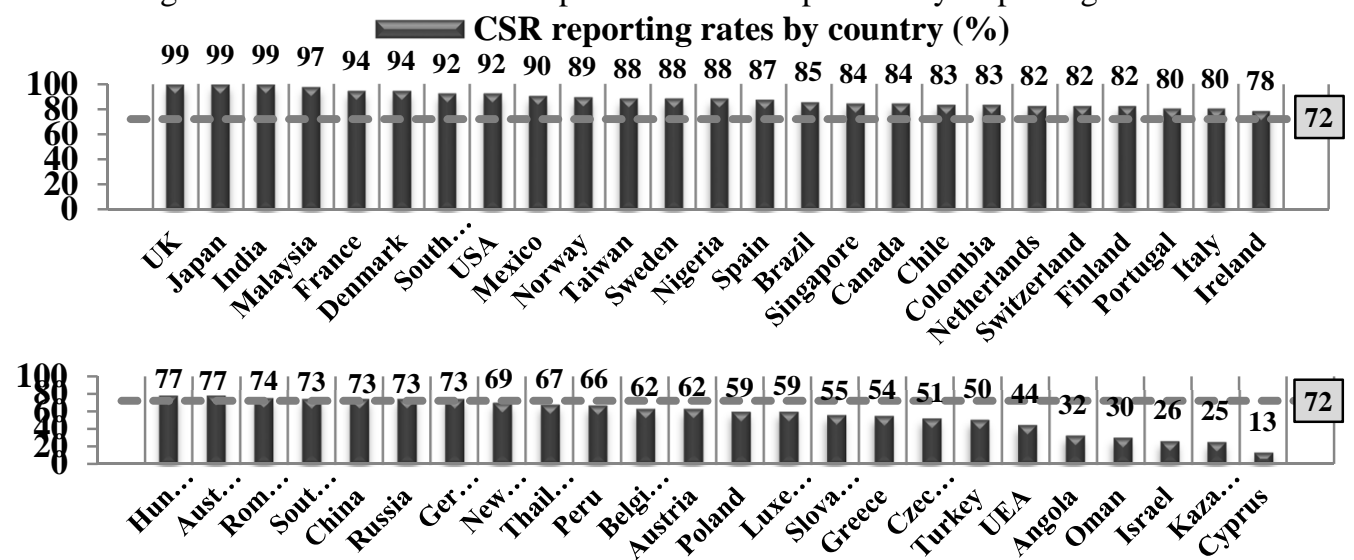

Source: Author's own work based on: (KPMG Survey of Corporate Social Responsibility Reporting 2017)

The number of reports registered in GRI Sustainability Disclosure Database also confirms the increasing interest in the concept of CSR reporting. It contains the social reports prepared by companies from various sectors and geographical region, regardless of form, reporting period, and thematic scope as well as the applied norms and guidelines concerning the area of corporate social responsibility reporting. More than 46.000 reports were registered since the beginning of GRI Sustainability Disclosure Database in 1999. An important issue is the gradual increase in number of registrations in both global and regional scale (figure 2).

Figure 2: Number of CSR reports published in the GRI Sustainability Disclosure ${ }^{10}$.

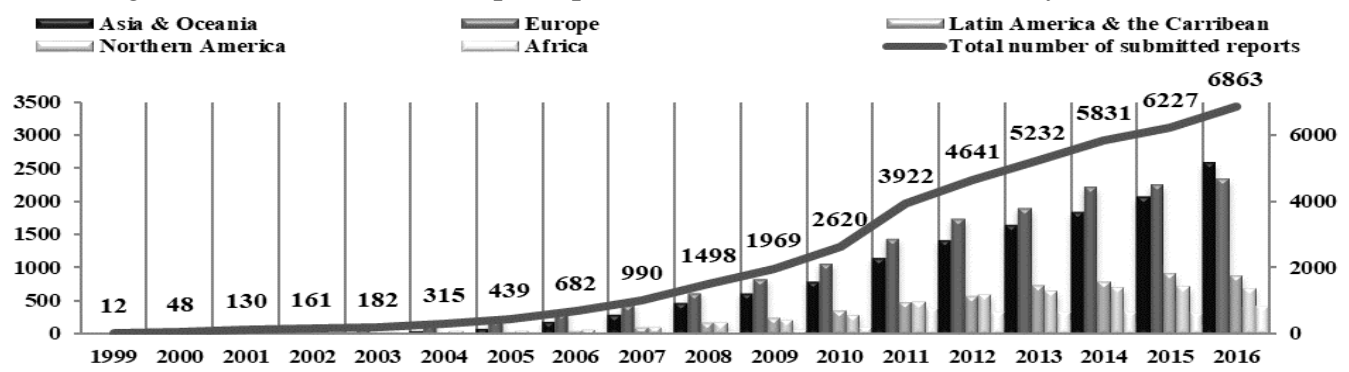

Selected countries in Europe

$2023 \quad 2006$

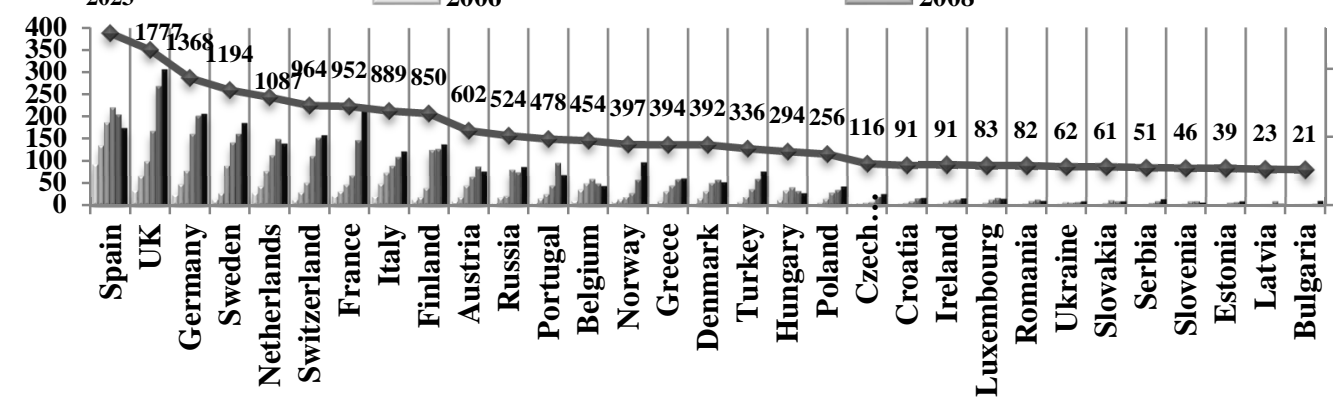

Source: Author's own work based on GRI Sustainability Disclosure Database

\footnotetext{
${ }^{10}$ The data for 2017 were omitted because of incompleteness.
} 
The growing interest in publishing CSR reports in the GRI Database can also be noted in activity of companies operating on the Polish market. Out of all 256 reports registered in the concerned period as many as 167 were prepared between 2013 and 2016. Moreover, it is expected that this increasing trend will continue in the future. This follows not only from the required to implement the Directive 2014/95/EU but also from the initiatives aimed at dissemination of non-financial reporting in Poland.

One of these initiatives is "Social Reports" contest organized since 2007, which rewards the best prepared reports in the field of corporate social responsibility The aim of the initiative is to increase the transparency of organizations' activities and show the good practices in social reporting. In the eleven editions of the contest, 275 reports were evaluated, of which record number of 44 reports were submitted in 2017. The fact that growing number of companies forgo the CSR reports and decide to publish integrated reports is also an important issue (figure 3 ).

Figure 3: Number of reports submitted to the "Social Reports" contest in 2007-2017.

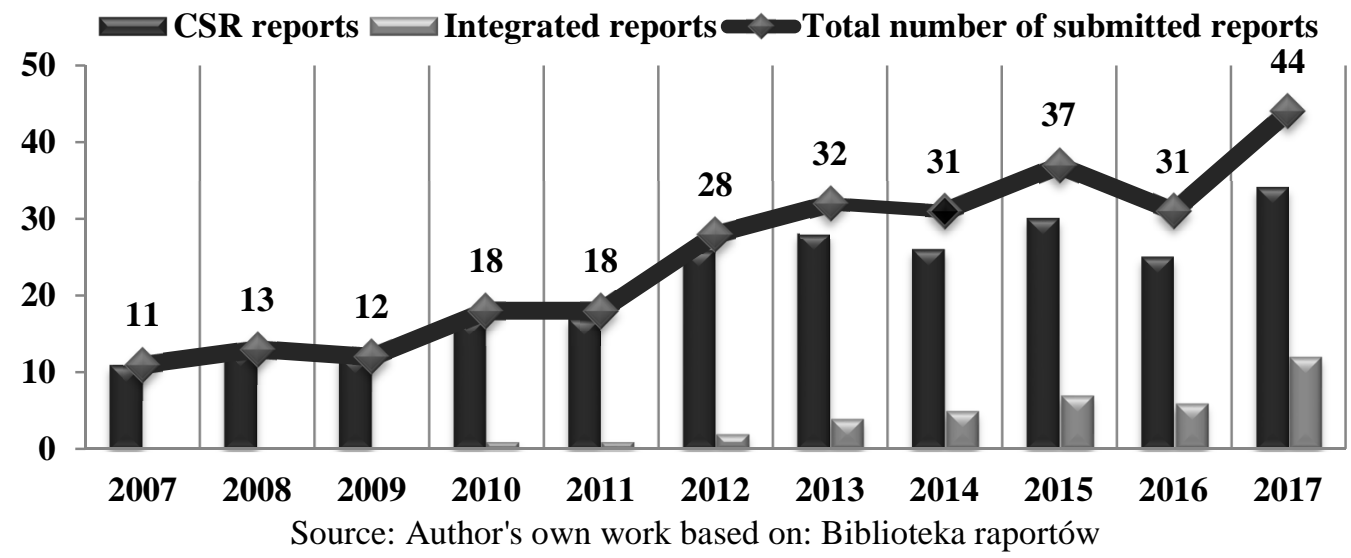

The procedure for evaluation of reports submitted to the "Social reports" contest is carried out in two stages. In the first stage, members of the jury consisting of experts in the field of economics, environmental protection, social issues and corporate social responsibility, individually evaluate the reports according to the criteria of completeness, trust and communication. The second stage involves the collate of individual evaluations and selection of best social reports. In the 2017 edition of "Social reports", contest awards went to the reports prepared by: CEMEX Polska, PKN ORLEN, Bank Zachodni WBK, Budimex, Lafarge and the Doctor Piotr Janaszek PODAJ DALEJ Foundation. The analysis of data contained in these reports allows the identification of key areas covered by the social reporting (table 1 ).

Table 1: Content of social reports awarded in the "Social Reports" contest in 2017.

\begin{tabular}{|c|c|c|c|c|}
\hline$\underset{\text { Organization }}{\text { Orame }}$ & Report name & Report & \multicolumn{2}{|c|}{ Report structure } \\
\hline $\begin{array}{c}\text { CEMEX } \\
\text { Polska } \\
\text { (sector: } \\
\text { construction) }\end{array}$ & $\begin{array}{c}\text { Sustainable } \\
\text { development } \\
\text { Report } \\
2015 / 2016\end{array}$ & $\begin{array}{l}\text { CSR } \\
\text { report }\end{array}$ & $\begin{array}{l}\text { 1. About us: (CEMEX in } \\
\text { Poland; CEMEX in the } \\
\text { World; Management } \\
\text { Board of CEMEX } \\
\text { Polska; CEMEX against } \\
\text { a background of a } \\
\text { construction sector; } \\
\text { Risk Management; } \\
\text { Awards } \\
\text { distinctions; } \\
\text { Membership and } \\
\text { Associations }\end{array}$ & $\begin{array}{l}\text { 5. Our employees: } \\
\text { (Employee profile; } \\
\text { Employee health and } \\
\text { safety; Programs to } \\
\text { improve safety in the } \\
\text { workplace; } \\
\text { Organizational } \\
\text { culture - a friendly } \\
\text { workplace; talent } \\
\text { development) on the } \\
\text { 6. Our impact on the } \\
\text { environment: }\end{array}$ \\
\hline
\end{tabular}




\begin{tabular}{|c|c|c|c|c|}
\hline & & & $\begin{array}{l}\text { 2. Our strategy: (OUR } \\
\text { vision; Sustainable } \\
\text { development strategy; } \\
\text { Ethics; Dialogue with } \\
\text { stakeholders; } \\
\text { Communication with } \\
\text { stakeholders) } \\
\text { 3. Our business: (Value } \\
\text { chain; business model; } \\
\text { Cooperation with } \\
\text { suppliers; Supply chain; } \\
\text { Responsible Production; } \\
\text { products; Sustainable } \\
\text { construction) } \\
\text { 4. Our customers: } \\
\text { (CEMEX customers; } \\
\text { Concentration } \\
\text { customers; Investments } \\
\text { with the participation of } \\
\text { CEMEX Polska } \\
\text { products) }\end{array}$ & $\begin{array}{l}\text { (Environmental } \\
\text { Protection } \\
\text { Management; } \\
\text { Environmental } \\
\text { impact; We build the } \\
\text { future in harmony } \\
\text { with nature; Our } \\
\text { environmental } \\
\text { education activities) } \\
\text { 7. Our neighbours: } \\
\text { (Social commitment; } \\
\text { CEMEX Poland's } \\
\text { Building the Future } \\
\text { Foundation; } \\
\text { Employee } \\
\text { Volunteering; } \\
\text { Foundation } \\
\text { numbers; Support for } \\
\text { local communities) } \\
\text { 8. About the report } \\
\text { (How we prepared } \\
\text { our report; Reporting } \\
\text { aspects; Independent } \\
\text { assurance report; } \\
\text { Employment at the } \\
\text { CEMEX Polska; } \\
\text { Environmental } \\
\text { performance; GRI } \\
\text { Content Index). }\end{array}$ \\
\hline $\begin{array}{l}\text { PKN } \\
\text { ORLEN } \\
\text { (sector: } \\
\text { energy) }\end{array}$ & $\begin{array}{c}\text { ORLEN } \\
\text { Group } 2016 \\
\text { Integrated } \\
\text { Report }\end{array}$ & $\begin{array}{l}\text { Integrated } \\
\text { report }\end{array}$ & $\begin{array}{l}\text { 1. The ORLEN Group and } \\
\text { its environment: (Letter } \\
\text { from the President of } \\
\text { the Management Board; } \\
\text { ORLEN Group 2016; } \\
\text { Our environment; Our } \\
\text { Report) } \\
\text { 2. Corporate Governance: } \\
\text { (Letter from the } \\
\text { Chairwoman of the } \\
\text { Supervisory Board; } \\
\text { Corporate governance at } \\
\text { PKN ORLEN; } \\
\text { Communication with } \\
\text { the capital market; } \\
\text { Major holdings of } \\
\text { shares; Special } \\
\text { shareholder rights; } \\
\text { General meetings in } \\
\text { 2016; Management and } \\
\text { supervisory bodies; } \\
\text { Remuneration policy } \\
\text { 3. Risks and opportunities: } \\
\text { (Risk Management; } \\
\text { Opportunities) } \\
\text { 4. Our strategy: (Strategy } \\
\text { implementation in 2014- } \\
\text { 2016; 2017-2021 } \\
\text { strategy; } \\
\text { Implementation } \\
\text { investments projects; } \\
\text { Monitoring of strategy } \\
\text { implementation; Market } \\
\text { outlook in 2017) }\end{array}$ & $\begin{array}{l}\text { 1. Financial results } \\
\text { (Consolidated } \\
\text { financial statements; } \\
\text { Auditor's opinion and } \\
\text { report; ORLEN in } \\
\text { figures) } \\
\text { 2. Our operations: } \\
\text { (Research and } \\
\text { development, Retail, } \\
\text { Downstream, Corporate } \\
\text { Upstream, Cunctions) } \\
\text { function } \\
\text { 3. Sustainable } \\
\text { development: } \\
\text { (Outlook CSR 2017+; } \\
\text { CSR } \\
\text { implementation; } \\
\text { Indirect economic } \\
\text { impacts; Diversity } \\
\text { and } \\
\text { opportunities; } \\
\text { Responsible } \\
\text { employer; Safety of } \\
\text { Employees } \\
\text { Contractors; and } \\
\text { Environmental } \\
\text { responsibility; } \\
\text { Responsibility } \\
\text { towards Customer; } \\
\text { Responsibility } \\
\text { towards Suppliers; } \\
\text { Product a } \\
\text { responsibility; } \\
\text { Society; Awards and } \\
\text { distinctions) } \\
\text { 4. Outlook 2017+ }\end{array}$ \\
\hline $\begin{array}{c}\text { Bank } \\
\text { Zachodni } \\
\text { WBK } \\
\text { (sector: } \\
\text { banking) }\end{array}$ & $\begin{array}{c}2016 \\
\text { Corporate } \\
\text { Social } \\
\text { Responsibility } \\
\text { Report }\end{array}$ & $\begin{array}{l}\text { CSR } \\
\text { report }\end{array}$ & $\begin{array}{l}\text { 1. About Bank Zachodni } \\
\text { WBK: (An interview } \\
\text { with the President; Who } \\
\text { We are; Santander } \\
\text { Group; How our impact } \\
\text { changed; Stakeholders }\end{array}$ & $\begin{array}{l}\text { 1. Employees: } \\
\text { (Priorities; } \\
\text { Employment } \\
\text { structure; Diversity; } \\
\text { Friendly workplace; } \\
\text { Benefits and work }\end{array}$ \\
\hline
\end{tabular}




\begin{tabular}{|c|c|c|c|c|}
\hline & & & 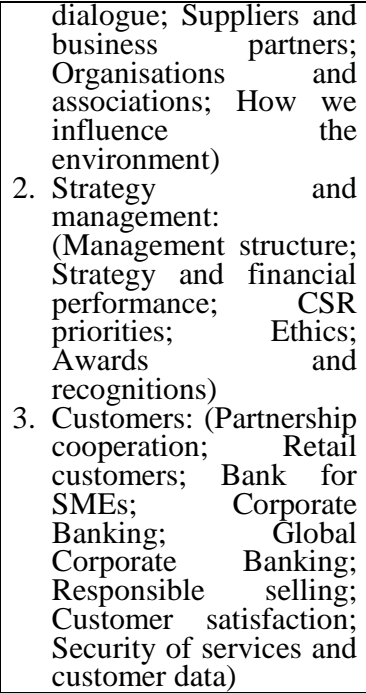 & $\begin{array}{l}\text { conditions; } \\
\text { Development; Health } \\
\text { and safety) } \\
\text { 2. Social engagement } \\
\text { (Our priorities; } \\
\text { Education and the } \\
\text { development of } \\
\text { science; Promoting } \\
\text { equal opportunities; } \\
\text { Support of social } \\
\text { initiatives; } \text { Bank } \\
\text { Zachodni } \text { WBK } \\
\text { Foundation) } \\
\text { 3. About the report: } \\
\text { (Reporting process; } \\
\text { Independent } \\
\text { assurance report; GRI } \\
\text { G4 Content Index; } \\
\text { Contact) }\end{array}$ \\
\hline $\begin{array}{l}\text { Budimex } \\
\text { (sector: } \\
\text { construction) }\end{array}$ & $\begin{array}{l}\text { Integrated } \\
\text { annual Report } \\
\text { for } 2016\end{array}$ & $\begin{array}{l}\text { Integrated } \\
\text { report }\end{array}$ & $\begin{array}{l}\text { 1. Letter from the } \\
\text { president } \\
\text { 2. Awards and distinctions } \\
\text { received in Poland in } \\
\text { 2016 } \\
\text { 3. About the company } \\
\text { 4. Market situation and } \\
\text { 5erspectives } \\
\text { 5. Last year's results } \\
\text { 6. Contribution } \\
\text { infrastructure } \\
\text { development } \\
\text { 7. Value model } \\
\text { 8. Management culture } \\
\text { 9. Managing responsibility } \\
\text { in the supply chain } \\
\text { 10. About the report } \\
\text { 11.Financial results }\end{array}$ & $\begin{array}{l}\text { 12. Conditions, } \\
\text { Occupational health } \\
\text { and safety } \\
\text { 13. Impact on the local } \\
\text { environment and } \\
\text { biodiversity with the } \\
\text { 14. Relations with } \\
\text { local communities of } \\
\text { 15. Prevention } \\
\text { unethical conduct and } \\
\text { honest acting in } \\
\text { business } \\
\text { 16.Quality and safety of } \\
\text { construction sites of } \\
\text { 17. Rational use of } \\
\text { resources } \\
\text { environmental and } \\
\text { pollution } \\
\text { 18. Non-financial data } \\
\text { tables } \\
\text { 19. Completion } \\
\text { strategy objectives for } \\
\text { 2016-2020 }\end{array}$ \\
\hline $\begin{array}{l}\text { Lafarge } \\
\text { (sector: } \\
\text { construction } \\
\text { materials) }\end{array}$ & $\begin{array}{c}\text { Sustainable } \\
\text { development } \\
\text { Report } 2016\end{array}$ & $\begin{array}{l}\text { CSR } \\
\text { report }\end{array}$ & $\begin{array}{l}\text { 1. About us: (An interview } \\
\text { with the President of } \\
\text { Lafarge in Poland; The } \\
2030 \\
\text { LafargeHolcim in the } \\
\text { world) } \\
\text { 2. In the interest of } \\
\text { business: (Sustainability } \\
\text { development; Good } \\
\text { cooperation; Ethics) } \\
\text { 3. In the interest of people: } \\
\text { (Our mission and } \\
\text { premonitions; Who We } \\
\text { are; Together - } \\
\text { LafargeHolcim } \\
\text { Foundation; We operate } \\
\text { together) }\end{array}$ & $\begin{array}{l}\text { 4. In the interest of } \\
\text { planet: (Sustainable } \\
\text { architecture; } \\
\text { Responsible supply } \\
\text { chain; innovations for } \\
\text { the environment) } \\
\text { 5. Basic information } \\
\text { about the company } \\
\text { 6. Guide to the report }\end{array}$ \\
\hline $\begin{array}{c}\text { Doctor Piotr } \\
\text { Janaszek } \\
\text { 'PODAJ } \\
\text { DALEJ' } \\
\text { Foundation } \\
\end{array}$ & $\begin{array}{l}\text { Social impact } \\
\text { report } 2016\end{array}$ & $\begin{array}{l}\text { CSK } \\
\text { report }\end{array}$ & $\begin{array}{l}\text { 1. History and Philosophy } \\
\text { 2. Mission and goals } \\
\text { 3. About the report and } \\
\text { stakeholders } \\
\text { 4. "PODAJ DALEJ" and } \\
\text { the United Nations }\end{array}$ & $\begin{array}{l}\text { 11. Good workplace } \\
\text { 12. Financial situation } \\
\text { 13. Rules and other } \\
\text { external initiatives } \\
\text { taken into account } \\
\text { by the "PODAJ }\end{array}$ \\
\hline
\end{tabular}




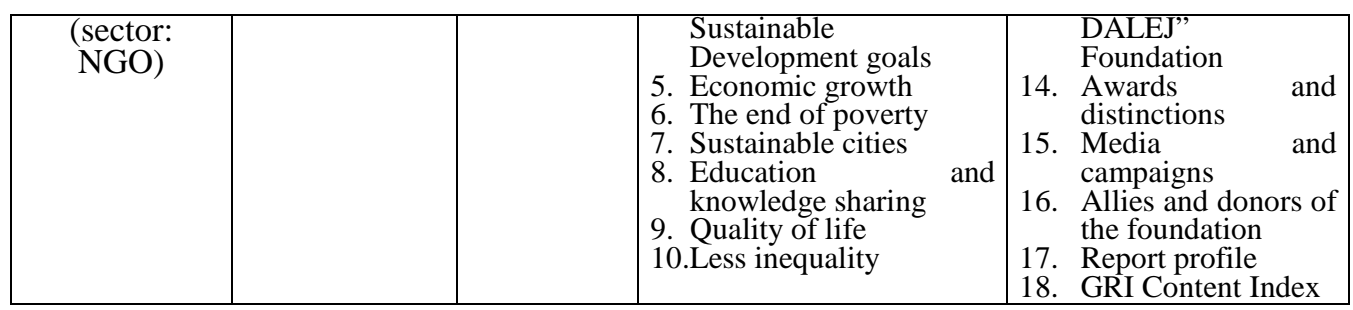

Source: Author's own work based on: 2016 Corporate Social Responsibility Report; Budimex Integrated annual Report for 2016; CEMEX - Raport zrównoważonego rozwoju 2015/2016, Raport oddziaływania społecznego 2016; Raport zrównoważonego rozwoju 2016; ORLEN

Group 2016 Integrated Report

The analysis of the content of reports considering in this article shows a wide range of information enabling the evaluation of a company's CSR strategy and the influence of its activity on environment. In contrast to financial statements, the social reports are the substantive basis for decision-making not only for investors but also for other stakeholders. They contain the information relating to environmental issues and relationships with various groups of stakeholders such as customers, employees and local community. Admittedly, these reports contain a number of commonly declared values. Nevertheless, they are characterized by both a varied scope of information as well as different structure of presentation.

\section{CONCLUSIONS}

The accounting described as a language of business which is being used by modern economic world has to be constantly changing. Nowadays, direction of these changes is determined by information society as well as development of the concepts of corporate social responsibility and sustainable development. This necessitates the need for development a system that reflects the processes which were previously outside the area of accounting. Social accounting is such a system. It aims at collecting and reporting the information referring to social and environmental issues.

Social reporting is a rapidly growing field in both national and international context. This is reflected by the number of reports dealing with corporate social responsibility submitted by companies to GRI Sustainability Disclosure Database and the "Social Reports" contest. Despite the growing numbers of companies which prepare their social or integrated reports, the comparison of data contained in individual reports may pose a considerable problem. Therefore, is becoming necessary to standardize delivered data, as in the case of financial statements.

\section{REFERENCES}

Biadacz, R. (2017). Rachunkowość społeczna w świetle badań polskich autorów, Zeszyty Teoretyczne Rachunkowości, 94 (150), 23.

Biblioteka raportów, http://raportyspoleczne.pl/biblioteka-raportow/ [accessed: 23.03.2018]

Bonsón, E., Bednárová, M. (2015). CSR reporting practices of Eurozone companies, Revista de Contabilidad - Spanish Accounting Review, 18(2), 182-193.

Budimex, Integrated Report for 2016, http://www.budimex.com.pl/repository/sustainability/Budimex_integrated_annual_report_2 016_ENG.pdf [accessed: 22.03.2018]

CEMEX, Raport zrównoważonego rozwoju 2015/2016, http://raportyspoleczne.pl/wpcontent/uploads/raports/047a1097583fd74fd99d31f9ed5ec54a.pdf [accessed: 22.03.2018] 
Corporate Social Responsibility Report 2016, Bank Zachodni WBK, https://raport.bzwbk.pl/en/ [accessed: 22.03.2018]

Directive 2014/95/EU of the European Parliament and of the Council of 22 October 2014 amending Directive 2013/34/EU as regards disclosure of non-financial and diversity information by certain large undertakings and groups (OJ L 330, 15.11.2014).

Gray, R., Owen, D., Maunders, K. (1987). Corporate Social Reporting Accounting \&Accountability, Prentice Hall, UK.

GRI Sustainability Disclosure Database, http://database.globalreporting.org/search/ [accessed: 18.03.2018].

Handel W. (1982). Ethnomethodology: How People Make Sense, Hemel Hempstead: PrenticeHall, quoted in Deegan C., Unerman J. (2006), Financial Accounting Theory, The McGrawHill Companies, London.

Islam, M. A. (2015). Social Compliance Accounting. Managing Legitimacy in Global Supply Chains, Springer International Publishing, Switzerland.

KPMG, The road ahead. The KPMG Survey of Corporate Social Responsibility Reporting 2017, https://home.kpmg.com/content/dam/kpmg/campaigns/csr/pdf/CSR_Reporting_2017.pdf, pp. 9-11.

Marcinkowska, M. (2013). Kapitat relacyjny banku. Ocena banku w kontekście relacji z interesariuszami, t. 3, Wydawnictwo Uniwersytetu Łódzkiego, Łódź, pp. 11-12.

Michalczuk, G. (2013). Zasoby niematerialne jako czynnik wartości przedsiębiorstwa. Luka informacyjna sprawozdawczości finansowej, Wydawnictwo Uniwersytetu w Białymstoku, Białystok, 159-271.

Michalczuk, G., Konarzewska, U., Mikulska, T. (2017), Raport zintegrowany jako przykład nowego podejścia do sprawozdawczości biznesowej przedsiębiorstw, Przedsiębiorstwo \& Finanse, 3(18), 47.

ORLEN Group 2016 Integrated Report, PKN ORLEN, https://raportzintegrowany2016.orlen.pl/en-2016 [accessed: 22.03.2018]

Raport oddziatywania społecznego 2016, Doctor Piotr Janaszek 'PODAJ DALEJ' Foundation, http://raportyspoleczne.pl/wp-

content/uploads/raports/e6a9f0c860595de324e2827415713e4d.pdf [acessed: 22.03.2018]

Raport zrównoważonego rozwoju 2016, Lafarge, http://raportyspoleczne.pl/wpcontent/uploads/raports/e22750b8a9cda02723e9b673f749a33b.pdf [accessed: 22.03.2018]

Zuchewicz, J. (2015). Wspótczesne determinanty rozwoju rachunkowości. „Prace Naukowe Uniwersytetu Ekonomicznego we Wrocławiu”, nr 388, p. 196. 